\title{
INFORMATION ON THE ENVIRONMENT AND ITS PROTECTION IN REAL PROPERTY MANAGEMENT
}

\author{
Małgorzata Dudzińska, PhD \\ Faculty of Geodesy and Land Management \\ University of Warmia and Mazury in Olsztyn \\ e-mail: gosiadudzi@uwm.edu.pl \\ Katarzyna Kocur-Bera, PhD \\ Faculty of Geodesy and Land Management \\ University of Warmia and Mazury in Olsztyn \\ e-mail:katarzyna.kocur@uwm.edu.pl
}

\begin{abstract}
Environmental protection regulations influence the use of real property. Land located within the borders of a national park or nature reserve is subject to partial or total restriction on development by construction, as well as, amongst others, business, trade, manufacturing or agricultural activities. Such areas are also subject to landscape protection, whereby real development by construction is possible, but only under the condition that it does not clash with the landscape values of the area. Therefore, real property management in such areas requires careful coordination with the relevant legislation concerning environmental protection.

While it is currently possible to obtain such information from existing environmental protection databases and systems, this has practical problems owing to the large amount of them and their scattered locations. Additionally, as each institution involved in environmental issues has collected material independently, there is a high level of data repetition as well as incomplete data. Such problems make it difficult to make full use of the database systems.

A lack of communication and reference between these databases and systems can create confusion. Comparative data on the same subject often differs depending on the source (as concerns graphic presentation and, much less frequently, data attributes). For example, the course of the same river differs depending on which data resources are used (NAEECZ 2007). There are several hundreds of databases and registers maintained in Poland, with almost 300 databases and registers controlled by the Ministry of Environment. Almost 60 such databases can be found in public administrative bodies alone. A portion of the data regarding this topic is openly available on the Internet.

The aim of the paper is to present the existing information systems concerning environmental protection. The paper will also examine data obtained from these resources, as well as their availability and connections with real property management activities.
\end{abstract}

Key words: property, management, environmental protection.

JEL Classification: R14, Q5.

Citation: Dudzińska M., Kocur-Bera K., 2014, Information on the environment and its protection in real property management, Real Estate Management and Valuation, vol. 22, no. 3, s. 93-103.

DOI: $10.2478 /$ remav-2014-0031 


\section{Introduction}

Environmental protection is a challenge to civilization, expressed by the provisions of the national constitution as well as international law. It frequently requires the limitation of ownership rights (or the exercising of those rights) while, on the other hand, it must consider the rights resulting from them. The limitations imposed by environment protection legislation represent one of many limitations in the use and management of real property. As a result of environmental protection, the legal limitations on real property use take precedence over many of the general rights of ownership, and it should be highlighted that environmental protection related limitations can restrict the use of real property very severely. In some cases, they may even make its use impossible in practical terms.

Article 130 of the Act - Environmental protection law indicates the regulations that may limit real estate use. First, such a limitation can take place as the result of subjecting the areas or objects to protection based on the provisions of the Act regarding the protection of nature (this includes national parks, nature reserves, landscape parks, etc.).

The establishment of protected areas is one of the key goals of the global conservation policy. This policy aims to achieve specific conservation objectives, particularly the preservation of biodiversity and critical ecological processes and ecosystems (CBD 1992, CHAPE et al. 2003, DUDLEY 2008, MiLLENNIUM ECOSYSTEM ASSESSMENT 2005, PIETRZYK-KASZYŃSKA et al. 2012). Networks of protected areas contribute significantly to the protection and maintenance of natural habitats (BRUNER et al. 2000). However, both the effectiveness of the protection efforts (ANDAM et al. 2008, GASTON et al. 2006 and HAYES 2006) and management are still open to discussion (HOCKINGS et al. 2006, STOLLKLEEMANN, 2010, PIETRZYK-KASZYŃSKA et al. 2012 and WWF, 2004).

The second limitation to real property ownership results from matters connected with water. This includes determining the conditions for the use of waters of a water region and establishing protected areas of inland water reservoirs based on the provisions of the water law. The restriction of ownership rights in this case results from the need to protect waters.

Thirdly, the limitation may be a consequence of establishing quiet areas within and outside of agglomerations.

Moreover, limitations in real property use for the purpose of protecting environmental resources may take place based on regulations regarding spatial planning and development. Such a limitation may result from the local plan covering areas that are subject to protection because of the natural environment or water resources. Such a limitation may also be imposed by a decision specifying the conditions for development by construction and land development.

Limitations in real property use have also been introduced by the Act on the protection of agricultural and forest land of 3 February 1995. According to the provisions of this Act, the use of land (of a specified area) for a purpose other than agricultural requires the drafting of a local plan and acceptance by the relevant administrative body.

Information on the imposed limitations should be held by those bodies conducting activities related to the management of the real properties. Frequently, such information can be obtained from the existing databases and systems of the environmental protection sector.

\section{Methodology of studies}

The presentation of the existing environmental protection databases and information systems useful in real property management was preceded by three research tasks:

1) Identification of environmental protection specifications concerning the implementation of tasks related to real property management.

2) Identification of existing databases and systems related to environmental protection, and the scope of information they contain.

3) Identification of systems and databases that might be useful in real property management, and information from these databases and systems that could be useful in real property management. 


\section{Environmental protection regulations effective when undertaking activities connected with real property management}

\subsection{Act of 16 April 2004 on Nature Protection}

The Act on nature protection plays a special role in the system of environmental protection legislation by protecting highly diversified resources within the natural environment that are of exceptional value to nature (BOROWIAK 2011). It outlines a number of different protection levels, starting with the protection of species, to the general protection of areas, trees and bushes of exceptional natural value, objects and areas of protection (including areas of Natura 2000), to the highest regime of protection represented by national parks and nature reserves (BOROWIAK 2011).

The basic forms of natural protection differ according to the purpose for which they were established, natural and cultural values (the level of preservation and importance to protecting the biodiversity of the entire country), and the systems of restrictions which significantly influence the methods of the economic use of lands situated within their limits (KRUK 2011).

According to the nature protection Act of 16 April 2004, the natural environmental protection system encompasses the following forms of protection: national parks, nature reserves, landscape parks, areas of protected landscapes, natural monuments, documentation sites, areas of ecological use, nature and landscape complexes, and areas of the European Ecological Network Natura 2000.

Table 1

Major limitations of the existing forms of protection

\begin{tabular}{|c|c|c|c|c|c|c|c|c|c|}
\hline \multirow[t]{2}{*}{ forms of protection } & \multicolumn{9}{|c|}{ type of ban } \\
\hline & 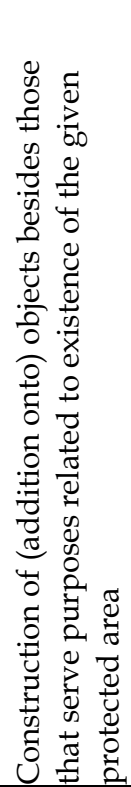 & 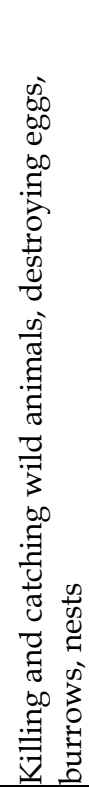 & 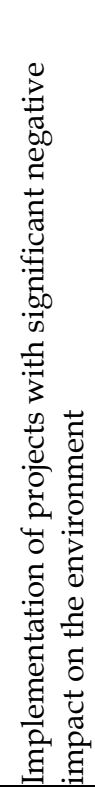 & 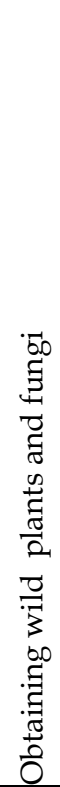 & 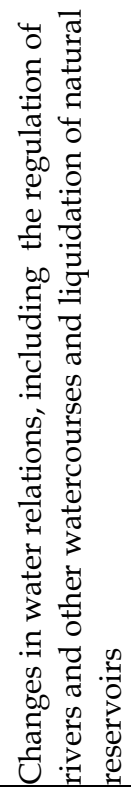 & 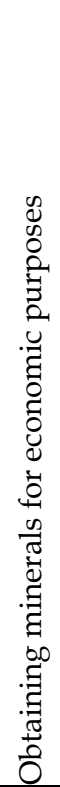 & 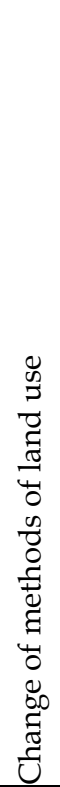 & 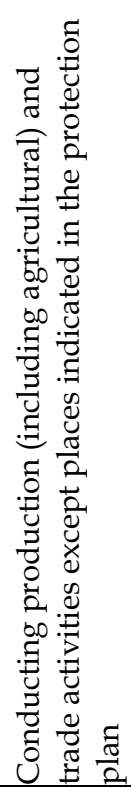 & 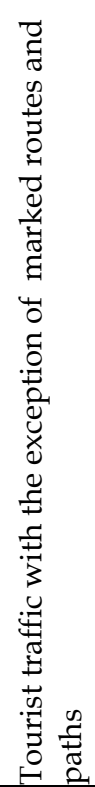 \\
\hline national parks & yes & yes & no & no & yes & yes & yes & yes & yes \\
\hline nature reserves & yes & yes & no & no & yes & yes & yes & yes & yes \\
\hline landscape parks & no & yes & no & yes & yes & yes & no & no & no \\
\hline $\begin{array}{l}\text { areas of protected } \\
\text { landscapes }\end{array}$ & no & yes & no & yes & yes & yes & no & no & no \\
\hline $\begin{array}{l}\text { monuments of nature, } \\
\text { documentation sites, } \\
\text { ecological use areas, nature } \\
\text { and landscape complexes }\end{array}$ & no & yes & no & yes & yes & yes & yes & no & no \\
\hline $\begin{array}{l}\text { European Ecological } \\
\text { Network - Natura } 2000\end{array}$ & no & yes & no & yes & yes & yes & yes & no & no \\
\hline protected refuge area & yes & yes & no & no & yes & yes & yes & yes & no \\
\hline
\end{tabular}

Source: own work based on POSKROBKO (2011). 
The most stringent protection rigors apply to the national parks and nature reserves. The restrictions concerning landscape parks are much less strict (table 1). Moreover, while all the bans which are compulsory in areas of national parks and nature reserves were listed in the Act on nature protection, in the case of landscape parks it was assumed that the bans may, but do not have to, be implemented at a given park. There is an increasingly common opinion that the bans are not strict and certain deviations are possible (with consent of the park director, who best knows the specific characteristics of the given area) (KRUK 2011).

Landscape protection also occurs in areas utilized for economic purposes. Landscape protection means that the development of real properties by construction is possible, but only in cases where it does not infringe on the landscape values of the area. When the given real property falls within the borders of a landscape park, bans can be implemented on the following activities: executing projects that could have a significant effect on the environment, obtaining minerals for economic purpose, conducting earth works and constructing buildings and structures within a $100 \mathrm{~m}$ radius of lake coasts and river banks.

When a real property falls within the limits of the Natura 2000 area, a compulsory ban on activities that could deteriorate the status of habitats is enforced. In the case of Natura 2000 areas, it should be clearly stated that limitations on the use of real properties may apply not only to real properties situated within the Natura 2000 area but also to other properties if the activities carried out on them may negatively affect Natura 2000 habitats (KOPROWSKI_2012).

\subsection{Act of 18 July 2001 - Water Law}

Determination of conditions for the use of water regions or basin waters, and determination of the protected areas of inland water reservoirs based on the provisions of the Water Law Act

In the case of protected areas of inland water reservoirs introduced under the Water Law Act, attention should first be drawn to those limitations resulting from establishing zones of direct or indirect protection of water intake points. In the direct protection zone, it is compulsory to develop the area with greenery, to fence the area off and to limit the presence of persons not directly needed there to a minimum.

Bans on establishing industrial plants, municipal waste and dangerous waste landfills, parking lots (camping sites, bathing sites) and housing or tourist structures, as well as extracting minerals and aggregate material (gravel, sand), installing drainage systems for construction or mining purposes, and practicing water sports can be imposed in the indirect protection zone. The requirement of cultivating appropriate agricultural and forest crops can also be imposed (KOPROWSKI 2012).

The Water Law Act also stipulates a ban on fencing real properties adjacent to public waters (up to $1.5 \mathrm{~m}$ from the shore). These provisions also make it impossible to impose a ban on passing through this area, or otherwise restricting such passage. Moreover, the Water Law Act introduces the duty of securing access to waters that are open for general use, and the duty to remove obstacles to and changes in water drainage, as well as a ban on the construction of structures less than 50 metres from the foot of the flood protection dyke.

\subsection{Act of 27 April 2001 Environment Protection Law}

Quiet areas in and outside of agglomerations.

The need to protect quiet areas is reflected in the Directive of 2002/49/EC (the Environmental Noise Directive) the aim of which is, among others, for Member States to accept Action Plans to preserve environmental noise levels in areas where the noise level is good (protection of quiet areas in open terrain ) (BERNAT 2011). The institution of quiet areas (both inside and outside of agglomerations) was introduced in the Environment Protection Law Act. A quiet area within an agglomeration is an area where sound levels remain below the permissible levels expressed by the LDWN (long-term average level of sound A expressed in decibels throughout the year, considering the daytime, evenings, and nights). A quiet area outside an agglomeration is an area that is not exposed to noise from transport, industry, or originating from recreational activities (article 3) (BERNAT 2011).

The designation of quiet areas is the responsibility of the poviat council and is binding to the instruments of planning and spatial development (art. 73 and 118b). This means that the local spatial development plan (decision on the conditions of development by construction and land development) may not allocate such areas for any activities that could result in increasing the noise level (LIPIŃSKI 
2005). Urban parks, small green areas, cemeteries, zoological gardens, places of religious significance, promenades and walkways (areas of recreational character) are examples of the preferred uses for quiet areas (BERNAT 2011). Additionally, it is necessary to determine quiet zones to secure the appropriate acoustic conditions in areas allocated for recreational purposes. For example, limitations or bans on the use of motor powered vessels can be implemented to cover specific water zones.

Moreover, the Environmental Protection Act also stipulates the institution of a limited use zone and an industrial zone. Within the limited use zone, restrictions can be implemented concerning the use of land and the specific technical requirements of buildings. With regard to the industrial zone area it is, in principle, possible to exceed the norms of environmental quality standards, though within the permissible limits of substances in the air and noise levels, when no threat to human life or health is posed, and safety and hygiene standards are not violated (KOPROWSKI 2012).

\subsection{Other legal regulations}

\section{Act of 27 March 2003 on spatial planning and development}

Limitations on the use of real property are dictated by restrictions of the technical aspects of construction and potential uses of the land and buildings. As this is legally binding to the owner, it may limit the planned utilization of the real property. The intended use of the area, parameters and indicators for development by construction, detailed principles and conditions of mergers and divisions of real properties, specific conditions for land development, and limitations on the use of the land, including the ban on development by construction, are defined in the local plan (KOPROWSKI 2012).

\section{Existing environment protection related databases and systems}

Spatial information systems can be found in practically every field from archaeological research, through application in business, to complex navigation technologies. This is due to the fact that the majority of organizations are of a geographic nature, that is to say that much of the data generated by them can be described by the location parameter (NAŁĘCZ 2007).

Geographic information systems have gained particular importance as a platform for building realistic models of spatial reference. With visualization systems supported by information technologies, geoinformation is now reaching new areas of the information society. Geographic information systems are more and more often aimed at satisfying the needs of public institutions and agencies, providing information on the area of operation and supporting decision-making processes involved in local to world-wide governance (LACH, ŁASZCZUK 2003). Geoinformation is of particular importance to analysts and planners, as well as decision-makers and those implementing planned activities concerning the human (and natural) environment (LACH, ŁASZCZUK 2003). The appropriate choice, collection, analysis and presentation of useful and reliable information to support planning and decision processes of operations represent an immensely important aspect of these systems.

\subsection{Databases on the environment in Poland}

No concept of the integrated Spatial Information System concerning nature has yet been developed in Poland. The task of building the local systems was entrusted to individual institutions. In that way, databases developed independently and so repeat much of the information. This would not pose a major problem if the repeated data originated from the same source. However, the individual projects were implemented in a rather secluded way, and the data was obtained independently (NAEECZ 2007). In practical terms, every institution gathered all the elements necessary to implement the project and, in many cases, demonstrated a text book example of repeating data resources.

The multitude of scattered databases concerning the monitoring of the environment means that the data contained in them is frequently repeated and incomplete, prohibiting full analysis and evaluation. When comparing data concerning the same subject but originating from different sources, it turned out that the data sets (Fig. 1) are not identical. The course of the same river differs depending on the source from which the data was obtained (NAŁĘCZ 2007).

There are almost 300 databases and registers for which the Ministry of the Environment is responsible. Almost 60 of them are in government administrative bodies alone. They are located at the Chief Inspectorate of Environmental Protection, the Voivodeship Inspectorate of Environmental Protection, the General Directorate for Environmental Protection, the Regional Directorate for Environmental Protection, the National Atomic Energy Agency and State Mining Authority, the 
National Water Management Authority, and the Ministry of the Environment itself. A list of the individual databases and registers contained at the individual government bodies has been presented in figure 1 .

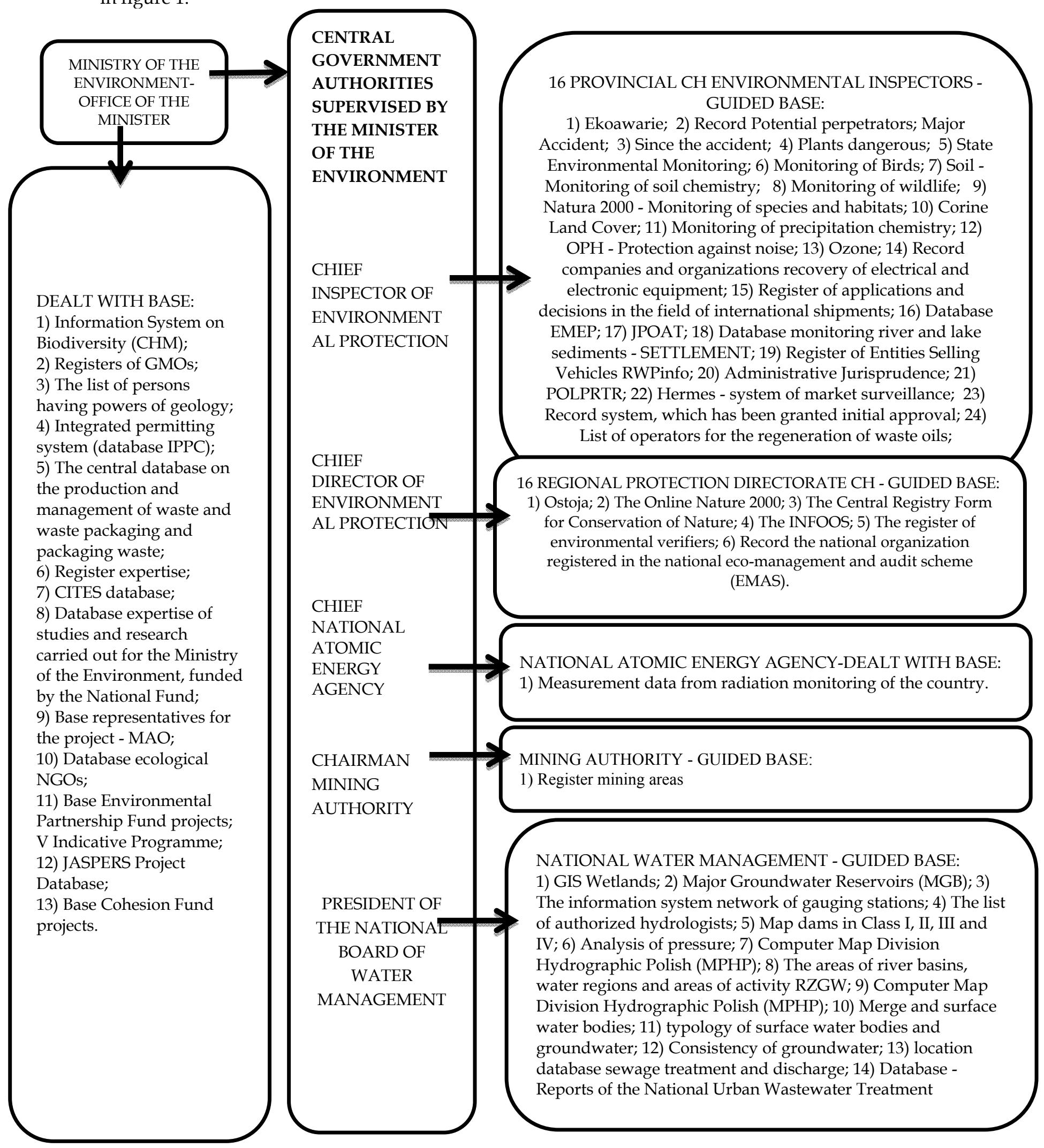

Fig. 1. Databases and registers maintained by government administrative bodies in the Ministry of the Environment. Source: own study based on EKOPORTAL.GOV.PL. 
In addition to the databases and registers maintained by government institutions, there are also databases of other entities subordinated to the Minister of the Environment. The largest number of such databases can be found at National Parks (around 140 as of 2011). The Centre of Information on the Environment has one database - the Eco-portal. The Forest Reproductive Material Office in Warsaw and the National Environment Protection and Water Management Fund have their own databases. The State Forests National Forest Holding has a large State Forest Information System (System Informatyczny Lasów Państwowych). What is more, Research and Development Units (Forest Research Institute, Institute for Ecology of Industrial Areas, Institute of Meteorology and Water Management - National Research Institute, Institute of Environmental Protection) all have their own databases (EKOPORTAL.GOV.PL).

The large number of registers and databases, as well as the poor interconnection between them, mean that, in addition to being duplicated, the data contained within is often not used by more than a single body or is exchanged in only a very limited extent.

\section{Information from the systems and databases related to environment protection useful in real property management}

The process of management is one of decision-making by the performer of the task. It is generally understood that a decision is associated with making choices, solving problems that emerge, determining the goals and directions of activities, as well as determining the methods and means of accomplishing them (KRZYWORZEKA 2012; DUDZIŃSKA, KOCUR-BERA 2013). The skill of obtaining important information, generating and processing, and next managing this bundle of new knowledge is immensely important. Being able to make a sound, informed decision at the appropriate stage allows a more efficient approach to problems and obstacles (WALCZAK 2012). Information can be obtained from different sources. Currently, some of the data is obtained from web services. Some of the most frequently used sources include elements of the Polish Spatial Information Infrastructure (relating to environmental protection: Natura 2000 Internet System - Geoserwis, the Central Register of the Forms of Environmental Protection - a part of Geoserwis, Ekoportal and Geoportal), which is currently is currently under development, as well as the Bulletin of Public Information.

Table 2 presents the databases and information systems from which it is possible to obtain information related to environmental protection concerning the forms of nature conservation, quiet zones and areas, as well as protected areas of inland water reservoirs. The part concerning the forms of nature conservation is presented specifically in Geoserwis, Ekoportal and Geoportal as well as Natura 2000 Internet System (fig. 2). These portals contain the boundaries of different forms of protection, prepared in different scales and on different background maps (fig. 2).

It is more difficult to obtain data concerning waters and quiet zones, and areas that are governed by the local legislation - through resolutions. The texts of these resolutions can be obtained from the Bulletin of Public Information of the issuing body (table 2). However, there are no compilations which present the borders of such zones and areas.

\section{Quality of data obtained}

Keeping in mind that the Polish Spatial Information Infrastructure is created based on the existing systems, registers and databases of spatial information, the data should be up to date and reliable.

The Polish Spatial Information Infrastructure under development encompasses the levels of the national as well as regional government. Works are currently aimed at improving the quality of the existing data sources, in line with the requirements of the INSPIRE Directive. In the report by BARANOWSKI (2009), it was concluded that the scope of information contained within the existing Polish data systems, NATURA2000 and the Central Register of the Forms of Nature Protection (part of Geoserwis), is consistent with the requirements of the INSPIRE Directive, but only in relation to nature protection. A change in the data set is necessary. The situation is similar with regards the Hydrographic Database - a Map of the Hydrographic Division of Poland (MPHP), a database of topographic objects (network of watercourses, still and flowing surface waters, hydrotechnical structures), which is consistent with the INSPIRE Directive requirements. Additional work, however, is necessary, particularly on the expansion of the databases and changing the structure of the data sets. The creation, completion and unification of data sets require the close collaboration of different administrative units, as well as gathering new data, which is very costly (BARANOWSKI 2009). 
Table 2

Data concerning environmental protection obtained from Internet services for the needs of real property management

\begin{tabular}{|c|c|c|c|c|}
\hline & $\begin{array}{c}\text { TYPES } \\
\text { OF } \\
\text { DATA }\end{array}$ & $\begin{array}{c}\text { DATABASES AND } \\
\text { SYSTEMSCONTAIN } \\
\text { ING NECESSARY } \\
\text { DATA } \\
\end{array}$ & $\begin{array}{l}\text { AVAILABILITY ON THE } \\
\text { INTERNET }\end{array}$ & RANGE OF DATA \\
\hline 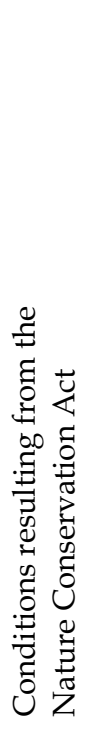 & 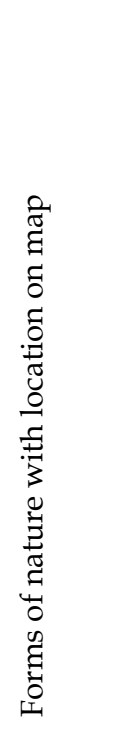 & $\begin{array}{l}\text { System Internetowy } \\
\text { Natura 2000_(Natura } \\
2000 \quad \text { Internet } \\
\text { System) } \\
\text { Geoserwis; } \\
\text { Centralny Rejestr } \\
\text { Form Ochrony } \\
\text { Przyrody - część } \\
\text { Geoserwisu (Central } \\
\text { Register of the Forms } \\
\text { of Nature Protection } \\
\text { - part of Geoserwis) } \\
\text { Ekoportal } \\
\text { Geoportal }\end{array}$ & $\begin{array}{l}\text { http://geoserwis.gdos.gov.pl/m } \\
\text { apy/ } \\
\text { http://crfop.gdos.gov.pl/CRFO } \\
\text { P/index.jsf } \\
\text { http://natura2000.eea.europa.eu } \\
\text { /\# } \\
\text { http://natura2000.gdos.gov.pl/ } \\
\text { datafiles/index/all:0/province_i } \\
\text { d:2 } \\
\text { geoportal.gov.pl } \\
\text { http://mapa.ekoportal.pl/ } \\
\text { geoportal.gov.pl }\end{array}$ & $\begin{array}{l}\text { 1) identification of terrain } \\
\text { functions - elements covered } \\
\text { by or requiring special } \\
\text { protection; } \\
\text { 2) identification of the } \\
\text { objectives of the given } \\
\text { protection; } \\
\text { 3) Data of the legal act on the } \\
\text { establishment, enactment or } \\
\text { appointment of an area } \\
\text { 4) Natura 2000 areas in } \\
\text { Europe } \\
\text { 5) Search for Natura } 2000 \\
\text { areas. }\end{array}$ \\
\hline 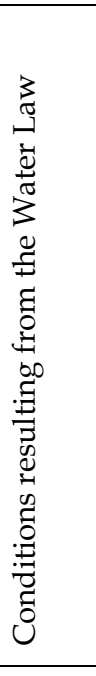 & 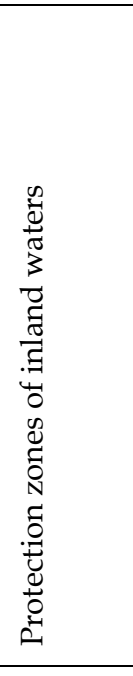 & $\begin{array}{l}\text { Geoportal } \\
\text { Water intake } \\
\text { protection zones - list } \\
\text { Bulletin of Public } \\
\text { Information - } \\
\text { Regional Water } \\
\text { Management } \\
\text { Authority }\end{array}$ & $\begin{array}{l}\text { http://geoportal.kzgw.gov.pl/i } \\
\text { map/ } \\
\text { http://www.warszawa.rzgw.go } \\
\text { v.pl/lewe_menu- } \\
\text { kataster_wodny2.html } \\
\text { http://www.bip.rzgw.gda.pl/? } \\
\text { mod=bip\&path=153,112,239 } \\
\text { http://www.rzgw.szczecin.pl/r } \\
\text { ozporzadzenia-dyrektora-rzgw- } \\
\text { szczecin } \\
\text { http://www.gliwice.rzgw.gov.pl } \\
\text { /index.php/pl/regionwodny/st } \\
\text { refy-ochronne-uj/strefy- } \\
\text { ochronne-uj }\end{array}$ & $\begin{array}{l}\text { Map of the Hydrographic } \\
\text { Division of Poland 2010; } \\
\text { List of regulations concerning } \\
\text { protection zones in Regional } \\
\text { Water Management Boards; } \\
\text { References to the contents of } \\
\text { the regulations. } \\
\text { Database of topographic } \\
\text { objects - network of } \\
\text { watercourses, still and } \\
\text { flowing surface waters, } \\
\text { hydrotechnical structures. }\end{array}$ \\
\hline 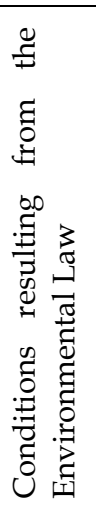 & 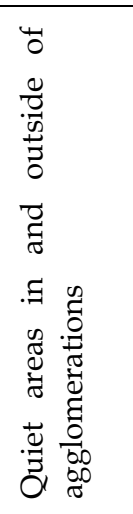 & $\begin{array}{l}\text { Bulletin of Public } \\
\text { Information - } \\
\text { resolutions of poviat } \\
\text { (county) councils } \\
\text { and voivodeship } \\
\text { sejmiks (assemblies) } \\
\\
\text { Local spatial } \\
\text { development plans }\end{array}$ & $\begin{array}{l}\text { E.g. } \\
\text { http://bip.powiat.kielce.pl/inde } \\
\text { x.php?go=3\&id_k=86 } \\
\text { http://www.wrotamalopolski.pl } \\
\text { /root_BIP/BIP_w_Malopolsce/r } \\
\text { oot_UM/podmiotowe/Sejmik/ } \\
\text { Uchwaly/ }\end{array}$ & 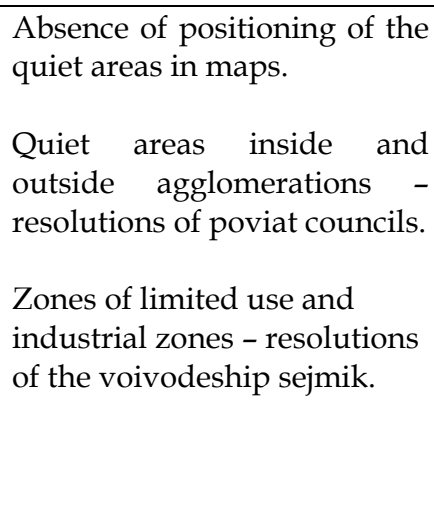 \\
\hline
\end{tabular}

Source: own study. 

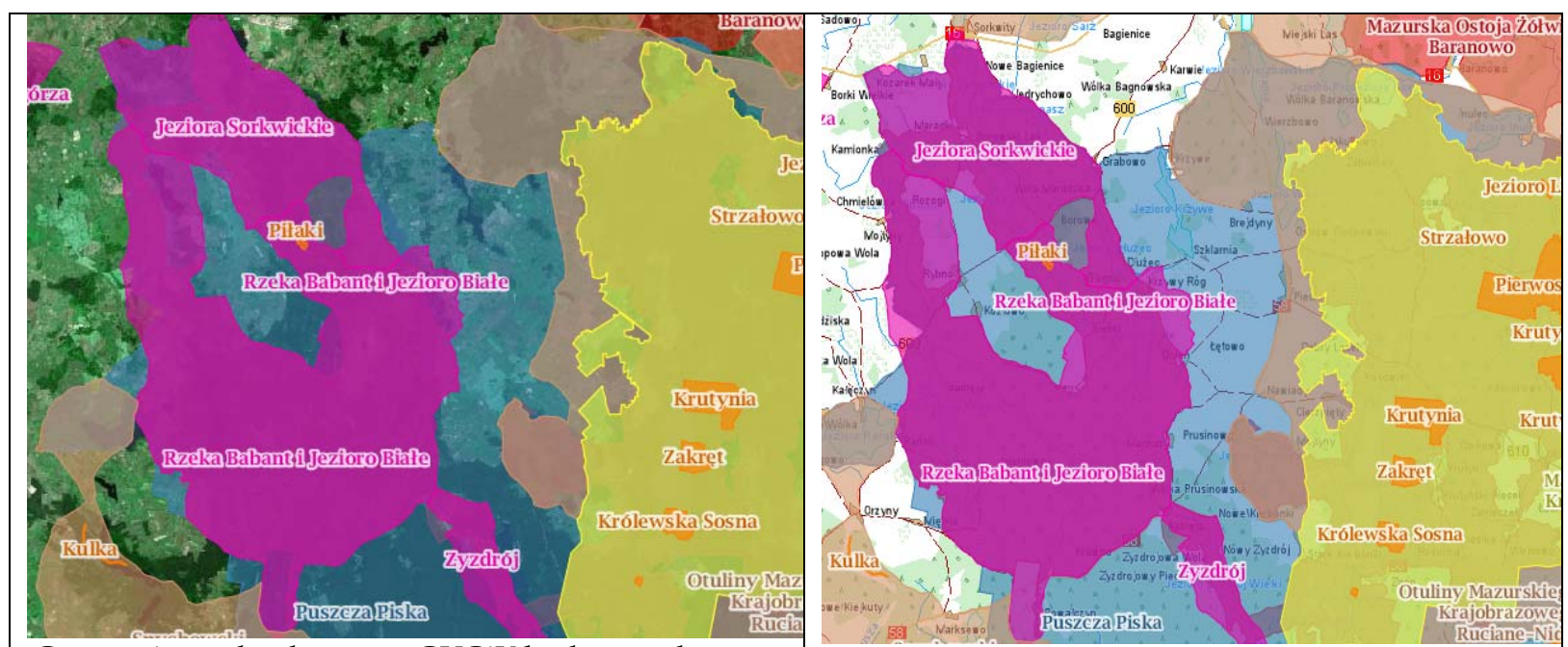

Geoserwis - orthophotomap GUGiK background

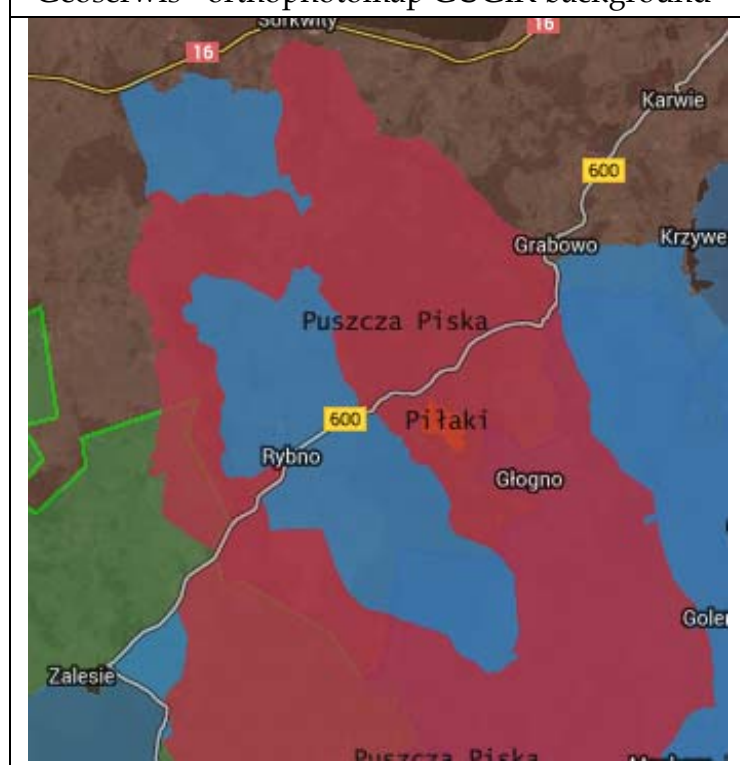

mapa.ekoportal.pl
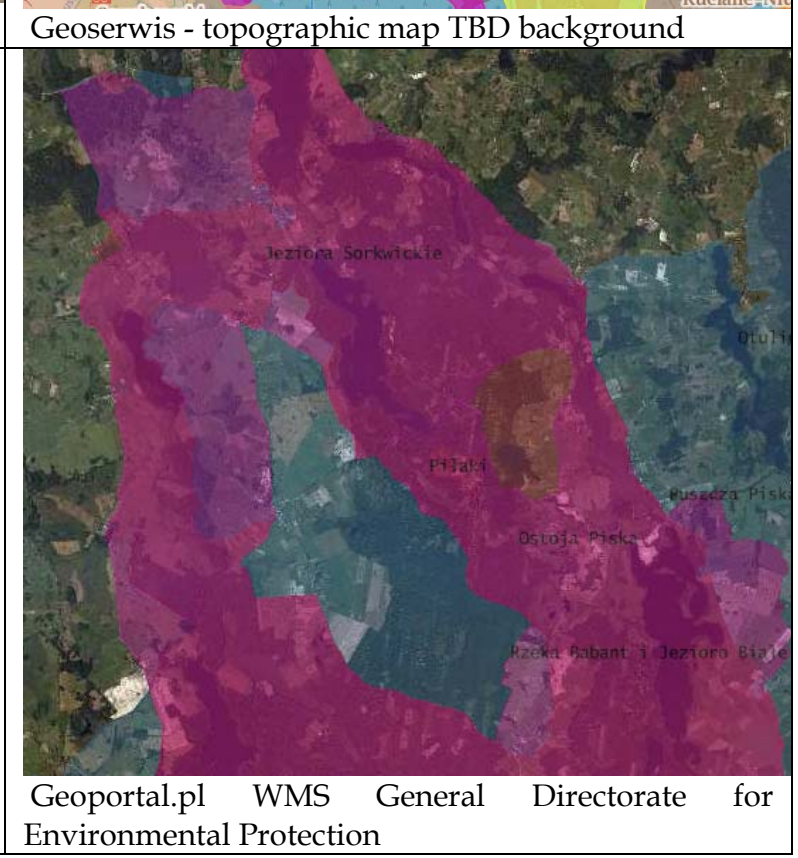

Fig. 2. Referenced maps with protected areas. Source: Own study

Other data available to real property management can be found on the Internet, on the Bulletin of Public Information concerning public bodies. The websites of the Bulletin available to the public are administrative sites of a purely informative character, publishing public information based on the Act of 6 September 2001 on access to public information.

\section{Conclusions}

Making the resources of the National Spatial Information Infrastructure (KIIP) widely available opens numerous new possibilities for citizens of the information society. This includes areas of gathering knowledge, as well as education and business opportunities. The resources of the system are becoming increasingly available and easier to access. They can provide additional sources of information. The conducted studies indicate that a significant part of the data is useful for real property management and can also be obtained easily. Still, there are no materials presenting the positioning of quiet areas or zones of limited use and industrial zones. Currently, works are in progress on expanding the scope and quality of the data in the information systems. This will form the National Spatial Information Infrastructure. The Bulletin of Public Information is yet another source of data allowing access to information on different subjects, e.g. related to environmental protection. It offers access to resolutions that form the local law. 


\section{References}

Andam K.S., Ferraro P.J., Pfaff A., Sanchez-Azofeifa G.A., Robalino J.A., 2008, Measuring the effectiveness of protected area networks in reducing deforestation Proceedings of the National Academy of Sciences of the United States of America, 105 (42), pp. 16089-16094.

BARANOWSKI M. I INNI, 2009, Prace nad identyfikacją zbiorów i ustug danych przestrzennych dla I i II grupy tematycznej INSPIRE, Instytut Geodezji i Kartografii, Warszawa.

BoROWIAK M., 2011, Wieloptaszczyznowość prawnej ochrony przyrody i jej wplyw na proces inwestycyjny. Prawo ochrony przyrody a procesy inwestycyjne. Towarzystwo Przyrodników Ziemi Łódzkiej pp. 21-33

BERNAT S., 2011, Krajobraz dźwiękowy jutra. (Soundscape of tomorrow) Niematerialne wartości krajobrazów kulturowych.( Prace Komisji Krajobrazu Kulturowego Nr 15 Komisja Krajobrazu Kulturowego PTG, Sosnowiec, pp. 193-205.

BRUNER A.G., GulLiSON R.E., RICE R.E., DA FONSECA G.A.B., 2000, Effectiveness of parks in protecting tropical biodiversity Science, 291 pp. 125-128

CBD, 1992 Convention on biological diversity United Nations

Chape S., Blyth S., Fish L., Fox P., SPALDing M., 2003, United nations list of protected areas IUCN/UNEP-WCMC, Gland, Switzerland/Cambridge, UK (2003)

DAWIDOWICZ A., ŹRÓBEK R., 2012, Determination of model attributes of a cadastral system in the light of recent scientific advancements. Reports and materials of the Polish Real Estate Scientific Society. Journal of the Polish Real Estate Scientific Society. 20/4, pp. 5-18.

DUDZIŃSKA M., 2011, Indicators for evaluating agricultural production areas. Infrastructure and ecology of rural areas. 01/2011, pp. 173-185.

DUDZIŃSKA M., KOCUR-BERA K., 2013, Studium wariantów podziału nieruchomości szpitalnej. (Study variants estate division hospital.) Wycena-Obrót-Wartość-Zarzadzanie Nieruchomościami $\mathrm{nr}$ 2(103), pp. 23-35

DUDLEY N., 2008 ${ }_{L}$ Guidelines for applying protected area management categories IUCN, Gland, Switzerland (2008)

DYREKTYWA 2007/2/WE Parlamentu Europejskiego i Rady z dnia 14 marca 2007 r. ustanawiająca infrastrukturę informacji przestrzennej we Wspólnocie Europejskiej (INSPIRE). (Dz.U. L $108 \mathrm{z}$ 25.4.2007)

DYREKTYWA 2002/49/WE Parlamentu Europejskiego i Rady z dnia 25 czerwca 2002 r. odnosząca się do oceny i zarządzania poziomem hałasu w środowisku

EKOPORTAL.GOV.PL - Witryna prowadzona przez Centrum Informacji o Środowisku. dostęp. 20.11.2013

GASTON K.J., CHARMAN K., JACKSON S.F., ARMSWORTH P.R., BONN A., BRIERS R.A., CALLAGHAN C.S.Q., CATChPOle R., Hopkins J.,. Kunin W.E, Latham J., Opdam P., StONEMAN R., STROUd D.A., TRATT R., 2006, The ecological effectiveness of protected areas: The United Kingdom Biological Conservation, 132 (2006), pp. 76-87

HAYES T.M., 2006, Parks, people, and forest protection: An institutional assessment of the effectiveness of protected areas World Development, 34, pp. 2064-2075

Hockings M., StOltON S., LeVERINGTON F., Dudley N., COURRAU J., 2006, Evaluating effectiveness: A framework for assessing management effectiveness of protected areas (2nd ed.)IUCN, Gland, Switzerland/Cambridge, UK (2006)

NAŁĘCZ T., 2007, Environmental spatial database integration. Challenge for the whole environmental trade? Roczniki Geomatyki., V/1, pp. 81-89.

KOPROWSKI A., 2012, Rola prawa ochrony środowiska w gospodarowaniu nieruchomościami (The role of environmental law in the management of real estate) http://czasopisma.beck.pl/nieruchomosci/artykul/rola-prawa-ochrony-srodowiska-wgospodarowaniu-nieruchomosciami/ dostęp. 20.01.2013

KRUK H., 2011, Działalność parków narodowych i krajobrazowych w zakresie rozwoju zrównoważonego wyniki badan (The activities of national parks and landscape in the field of sustainable development - the results of) - Planistyczne i implementacyjne aspekty rozwoju obszarów przyrodniczo cennych, Wyższa Szkoła Ekonomiczna, Białystok, pp. 143-150.

KRZYWORZEKA A., KRZYWORZEKA P., 2012, Etnografia w badaniu wiedzy ukrytej, „e-mentor” (Ethnography in the study of tacit knowledge, "e-mentor), nr 1 (43), pp. 66-69. 
LACH Z., ŁASZCZUK A., 2003, Rola i znaczenie systemów informacji geograficznej w działalności na rzecz bezpieczeństwa polski. ( The role and importance of geographical information systems in the activities to support the security of Poland) Roczniki Geomatyki 1/1, pp. 26-37.

LIPIŃSKI A., 2005: Ochrona przed hałasem - znowelizowane prawo ochrony środowiska. (Noise protection an amendment of the environment protection law) Bezpieczeństwo Pracy 7-8, pp. 10-14.

MILLENNIUM ECOSYSTEM ASSESSMENT, 2005 Ecosystems and human well-being: Synthesis Island Press, Washington, DC (2005)

PIETRZYK-KASZYŃSKA A., CENT J., GRODZIŃSKA-JURCZAK M., SZYMAŃSKA M., 2012 Factors influencing perceptron of protected areas - The case of Natura 2000 in Polish Carpathian communities Journal for Nature Conservation, 20 , pp. 284-292

POSKROBKO T. (red), 2011, Planistyczne i implementacyjne aspekty rozwoju obszarów przyrodniczo cennych. (Planning and implementing aspects of the development of valuable natural areas.) Zrównoważony rozwój obszarów przyrodniczo cennych. Tom 1. Białystok.

STOLL-KLEEMANN S., 2010, Evaluation of management effectiveness in protected areas: Methodologies and results Basic and Applied Ecology, 11 , pp. 377-382

WALCZAK W., 2012, Czynniki i uwarunkowania wptywajace na decyzje w zarzadzaniu organizacja..( Factors and conditions influencing the decisions in the management of the organization) E-mentor $\mathrm{nr} 3$ (45), pp. 35-45.

WWF, 2004, Are protected areas working? An analysis of forest protected areas by WWF Published by WWF for the Seventh Conference of Parties of the Convention on Biological Diversity, Gland, Switzerland

USTAWA z dnia 18 lipca 2001r. Prawo wodne (Dz. U. z 2005 r. Nr 239, poz. 2019 z późn. zm.)

USTAWA z dnia 16 kwietnia 2004 r. o ochronie przyrody (Dz. U. z 2009 r. Nr 151, poz. 1220 z późn. zm.)

USTAWA z dnia 27 kwietnia 2001 r., Prawo ochrony środowiska, (Dz. U. 2001 nr 62, poz. 627 z późn. $\mathrm{zm}$.)

USTAWA z dnia 27 marca 2003 o zagospodarowaniu i planowaniu przestrzennym.( Dz. U. z 2012 r. poz. 647, z późn. zm.) 